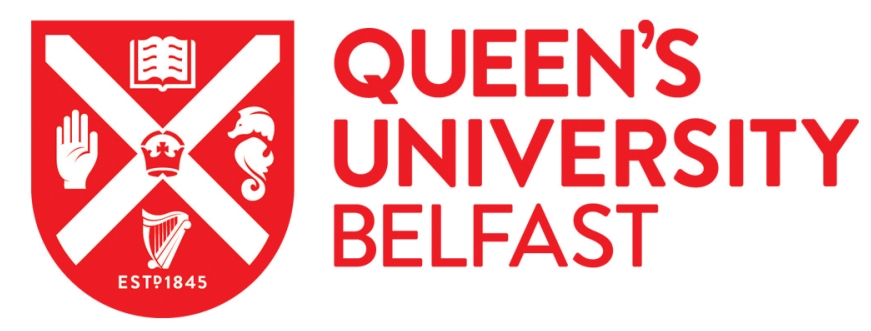

\title{
Arbuscular mycorrhizal fungi associated with sedges on the Tibetan plateau
}

Gai, J. P., Cai, X. B., Feng, G., Christie, P., \& Li, X. L. (2006). Arbuscular mycorrhizal fungi associated with sedges on the Tibetan plateau. Mycorrhiza, 16(3), 151-157. https://doi.org/10.1007/s00572-005-0031-8

\section{Published in:}

Mycorrhiza

\section{Queen's University Belfast - Research Portal:}

Link to publication record in Queen's University Belfast Research Portal

\section{General rights}

Copyright for the publications made accessible via the Queen's University Belfast Research Portal is retained by the author(s) and / or other copyright owners and it is a condition of accessing these publications that users recognise and abide by the legal requirements associated with these rights.

Take down policy

The Research Portal is Queen's institutional repository that provides access to Queen's research output. Every effort has been made to ensure that content in the Research Portal does not infringe any person's rights, or applicable UK laws. If you discover content in the Research Portal that you believe breaches copyright or violates any law, please contact openaccess@qub.ac.uk. 


\section{J. P. Gai · X. B. Cai • G. Feng • P. Christie • X. L. Li \\ Arbuscular mycorrhizal fungi associated with sedges on the Tibetan plateau}

Received: 4 May 2005 / Accepted: 28 October 2005 / Published online: 4 January 2006

C) Springer-Verlag 2006

\begin{abstract}
The arbuscular mycorrhizal (AM) status of nine dominant sedge species and the diversity of AM fungi in Tibetan grassland were surveyed in the autumn of 2003 and 2004. Most of the sedge species and ecotypes examined were mycorrhizal, but Carex moorcroftii and Kobresia pusilla were of doubtful AM status, and Kobresia humilis was facultatively mycorrhizal. This is the first report of the mycorrhizal status of eight of the nine sedge species examined. Intraradical vesicles and aseptate hyphae were the structures most frequently observed. Appressoria, coils, and arbuscules were found in the roots of a few sedge species. A strong negative correlation was found between soil organic matter content and the extent of mycorrhizal colonization. Using trap cultures, 26 species of AM fungi belonging to six genera, Glomus, Acaulospora, Paraglomus, Archaeospora, Pacispora, and Scutellospora, were isolated from the soil samples collected. The frequency of occurrence of different taxa of AM fungi varied greatly. Glomus and Acaulospora were the dominant genera, and Acaulospora scrobiculata was the most frequent and abundant species. The species richness of AM fungi was 2.73 in the study area. Species richness and diversity index differed among the sedge species but were not correlated with soil factors such as $\mathrm{pH}$, available $\mathrm{P}$, or organic matter content.
\end{abstract}

\footnotetext{
J. P. Gai · G. Feng · P. Christie · X. L. Li ( $\)$

Department of Plant Nutrition, China Agricultural University,

2 Yuanmingyuan Road,

Beijing 94, China

e-mail: lixl@cau.edu.cn

Tel.: +86-10-62731325

Fax: +86-10-62731016

X. B. Cai

College of Agricultural and Animal Husbandry,

University of Tibet,

Linzhi 860000, China

P. Christie

Agricultural and Environmental Science Department,

Queen's University Belfast,

Newforge Lane, Belfast BT9 5PX, UK
}

Keywords Sedges $\cdot$ Arbuscular mycorrhiza $\cdot$ Fungal structure $\cdot$ Grassland $\cdot$ Species diversity $\cdot$ Tibet

\section{Introduction}

About $80 \%$ of terrestrial plant species in natural ecosystems are mycorrhizal, and the associations may improve the fitness of the fungal and plant partners (Smith and Read 1997). Ecologists have taken increasing interest in the incidence and ecological role of arbuscular mycorrhizal (AM) fungi in natural plant communities in recent years (Bever 2002; Bever et al. 2001; Burrows and Pfleger 2002). Despite the occurrence of mycorrhiza in the great majority of modern plant taxa and in almost all ecosystems, there are still some plant families such as Cyperaceae, Brassicaceae, Caryophyllaceae, Juncaceae, and Amaranthaceae presumed to be nonmycorrhizal or rarely mycorrhizal (Newman and Reddell 1987; Peterson and Bradbury 1995; Hirsch and Kapulnik 1998; Regvar et al. 2003; Fuchs and Haselwandter 2004). The Cyperaceae have become particularly prominent in recent years for the many conflicting reports on their mycorrhizal status.

Sedges often dominate wetlands and arctic and alpine vegetation in which the mycorrhizal inoculum is often low or absent and were therefore often designated nonmycorrhizal (Harley and Harley 1987; Tester et al. 1987). However, Muthukumar et al. (2004) recently reviewed the current information on mycorrhizal associations in sedges and showed that the family can no longer be considered nonmycorrhizal. Indeed, the mycorrhizal status of its members seems to be greatly influenced by environmental conditions. Since 1987, information has become available for 221 sedge species, indicating that $88(40 \%)$ are mycorrhizal, $109(49 \%)$ are nonmycorrhizal, and 24 (11\%) are facultatively mycorrhizal. There are still many sedge species that remain to be investigated, and detailed information on the AM fungal composition and community diversity in sedges is still unavailable. Further, functional aspects of the association in the extreme environments that sedges often inhabit remain unclear. 
Tibet $\left(26^{\circ} 44^{\prime}-36^{\circ} 32^{\prime} \mathrm{N}, 78^{\circ} 25^{\prime}-99^{\circ} 06^{\prime} \mathrm{E}\right)$ is the world's largest and highest plateau. The average altitude is about 4,500 $\mathrm{m}$ above sea level, and the weather differs sharply during day and night. Because of the different geographical conditions, contrasting temperatures are found in the north and south. The north has a continental climate, and the south is relatively warm and rainy. Grassland is very important because of the harsh geographical and climatic conditions, occupying 82.07 million hectares of the Tibetan plateau. The main types of grassland are alpine steppes, alpine meadow grasslands, alpine meadows, and montane scrub. Poaceae, Cyperaceae, and Asteraceae are the three most important plant families in terms of abundance, herbage quality, productivity, and distribution for pastoral agriculture. Most of the sedges, especially Kobresia, occur in the high quality pasture, and information is required on the mycorrhizal status and ecological role of AM associations in sedges. However, there are no reports on the mycorrhizal status of sedges on the Tibetan plateau.

The objectives of the present study were to determine the mycorrhizal status of the dominant sedge species, Kobresia humilis, Kobresia prainii, Kobresia pygmaea, and Carex moorcroftii, and to assess the diversity of AM fungi in the rhizosphere of sedges in Tibetan grassland. The relationships between the extent of AM colonization and soil properties (soil $\mathrm{pH}$, organic matter content, and available $\mathrm{P}$ ) were also investigated.

\section{Materials and methods}

Sampling area and procedures

The investigation was conducted in the prefectures of Lhasa, Rikaze, Shannan, and Naqu $\left(29^{\circ} 19^{\prime}-32^{\circ} 52^{\prime} \mathrm{N}, 88^{\circ}\right.$ $57^{\prime}-92^{\circ} 20^{\prime} \mathrm{E}$ ). Soils and roots were sampled in the grasslands at altitudes ranging from 3,798 to $5,220 \mathrm{~m}$ above sea level. The climate of this region from north to south varies from alpine plateau to a semiarid type of temperate climate. The mean annual temperature is -1.2 to $8^{\circ} \mathrm{C}$, and annual precipitation is about $300-450 \mathrm{~mm}$.

Vegetation types are mainly montane scrub, alpine steppe, alpine meadow grassland, and alpine meadow. The dominant sedge species in the different types of grassland were sampled in this study. In the autumn of 2003 and 2004, 22 soil samples were collected from the rhizosphere of nine sedge species in the main grasslands. The sedge species selected are often dominant and scattered among dense grasses in the sampling areas. Three or more plants were dug out together from each sampling point, and

Table 1 Sedges examined, vegetation type, altitude, soil characteristics, and AM status of Tibetan sedges

\begin{tabular}{|c|c|c|c|c|c|c|c|c|c|}
\hline Host plants & $\begin{array}{l}\text { Land } \\
\text { type }\end{array}$ & $\begin{array}{l}\text { Altitude } \\
(\mathrm{m})\end{array}$ & $\begin{array}{l}\text { Soil } \\
\text { texture }\end{array}$ & $\begin{array}{l}\text { Organic } \\
\text { matter } \\
(\mathrm{g} / \mathrm{kg})\end{array}$ & $\begin{array}{l}\text { Olsen-P } \\
(\mathrm{mg} / \mathrm{kg})\end{array}$ & $\mathrm{pH}$ & $\begin{array}{l}\text { AM fungal } \\
\text { structures }\end{array}$ & $\begin{array}{l}\text { Colonization } \\
(\%)\end{array}$ & $\begin{array}{l}\text { Spore } \\
\text { density } \\
(\text { per } 20 \mathrm{~g} \text { ) }\end{array}$ \\
\hline Carex capillacea var. linzensis & MS & 3980 & Loam & 5.47 & 5.23 & 6.74 & ar, $\mathrm{v}, \mathrm{h}$ & $30.3 \pm 8.5$ & 66 \\
\hline $\begin{array}{l}\text { C. capillacea var. } \\
\text { linzensis }\end{array}$ & LM & 3977 & Loam & 1.51 & 10.35 & 6.47 & $\mathrm{v}, \mathrm{h}$ & $31.8 \pm 10.2$ & 10 \\
\hline C. moorcroftii & AMG & 5220 & Sandy loam & 1.82 & 14.99 & 6.67 & $\mathrm{v}, \mathrm{h}$ & $22.7 \pm 5.9$ & 30 \\
\hline C. moorcroftii & AT & 4510 & Gravel soil & 3.68 & 17.08 & 8.19 & $\mathrm{v}, \mathrm{h}$ & $22.1 \pm 4.1$ & 79 \\
\hline C. tibetica & MS & 3798 & Sand & 0.09 & 62.16 & 7.55 & $\mathrm{v}, \mathrm{h}, \mathrm{c}$ & $30.9 \pm 12.3$ & 17 \\
\hline C. compressus & $\mathrm{AM}$ & 4827 & Loam & 3.60 & 6.65 & 6.03 & ar, $\mathrm{v}, \mathrm{h}$ & $25.3 \pm 6.7$ & 10 \\
\hline C. compressus & $\mathrm{AM}$ & 4827 & Loam & 5.46 & 5.25 & 6.01 & ar, $\mathrm{v}, \mathrm{h}$ & $17.7 \pm 2.0$ & 120 \\
\hline C. compressus & $\mathrm{AM}$ & 4394 & Loam & 2.11 & 6.36 & 6.26 & ar, $\mathrm{v}, \mathrm{h}$ & $51.3 \pm 15.7$ & 48 \\
\hline C. compressus & $\mathrm{AM}$ & 4857 & Loam & 8.29 & 8.44 & 6.02 & ar, $\mathrm{v}, \mathrm{h}$ & $20.1 \pm 3.2$ & 23 \\
\hline C. compressus & $\mathrm{AM}$ & 4827 & Loam & 8.36 & 5.15 & 6.1 & ar, $\mathrm{v}, \mathrm{h}$ & $19.9 \pm 1.9$ & 42 \\
\hline K. humilis & $\mathrm{AM}$ & 4385 & Loam & 2.51 & 15.2 & 7.03 & ar, $\mathrm{v}, \mathrm{h}$ & $34.2 \pm 10.1$ & 58 \\
\hline K. humilis & $\mathrm{AMG}$ & 5138 & Sand & 2.58 & 9.67 & 6.86 & $\mathrm{v}, \mathrm{h}$ & $37.9 \pm 3.8$ & 16 \\
\hline K. humilis & $\mathrm{AM}$ & 4789 & Loam & 11.56 & 12.45 & 6.97 & ND & 0 & 14 \\
\hline K. humilis & AS & 4559 & Loam & 2.09 & 18.17 & 6.75 & ap, $\mathrm{v}, \mathrm{h}$ & $42.7 \pm 14.7$ & 72 \\
\hline K. humilis & $\mathrm{AM}$ & 4455 & Loam & 3.57 & 11.45 & 6.37 & $\mathrm{v}, \mathrm{h}$ & $35.2 \pm 8.9$ & 24 \\
\hline K. prainii & AMG & 4897 & Loam & 8.13 & 9.64 & 7.15 & ap, ar, v, h & $65.0 \pm 16.4$ & 16 \\
\hline K. prainii & AS & 4543 & Gravel soil & 0.82 & 1.78 & 7.39 & ap, $\mathrm{v}, \mathrm{h}$ & $30.0 \pm 2.9$ & 70 \\
\hline K. pusilla & $\mathrm{AMG}$ & 4717 & Loam & 7.78 & 11.02 & 7.92 & $\mathrm{v}, \mathrm{h}$ & $6.1 \pm 1.4$ & 87 \\
\hline K. pusilla & AT & 4837 & Loam & 3.06 & 7.49 & 6.61 & $\mathrm{v}, \mathrm{h}$ & $48.1 \pm 12.9$ & 24 \\
\hline K. pygmaea & AMG & 5006 & Gravel soil & 0.36 & 2.94 & 8.18 & ap, h & $10.6 \pm 1.9$ & 189 \\
\hline K. pygmaea & AS & 4603 & Silty soil & 3.28 & 5.14 & 8.48 & ar, $\mathrm{v}, \mathrm{h}$ & $15.3 \pm 3.2$ & 8 \\
\hline K. tibetica & AMG & 4738 & Sand & 1.76 & 9.25 & 8.11 & ar, $\mathrm{v}, \mathrm{h}$ & $56.0 \pm 2.7$ & 16 \\
\hline
\end{tabular}

$A M$, Arbuscular mycorrhizal, $A p$ appressoria, ar arbuscules, $h$ intercellular aseptate hyphae, $v$ vesicles, $c$ coils, $N D$ not detected, $A M G$ alpine meadow grassland, $A S$ alpine steppe, $A M$ alpine meadow, $M S$ montane scrub, $L M$ lowland meadow 
Fig. 1 Fungal colonization in Tibetan grassland sedges. a Arbuscule (a), intraradical hyphae, and vesicle (v) in root of $K$. prainii. b Intraradical hyphae and vesicle (v) in cells of $C$. moorcroftii. c Vesicle (v) and intraradical hyphae in cells of $K$. humilis. d Extramatrical K. pygmaea root. e Intraradical hyphae and vesicle (v) in root of Carex capillacea var. linzensis. f Hyphal coil (hc) formation on C. tibetica root. g Intraradical hyphae (h) and vesicle in root of $C$. compressus. h Appressorium (ap) formation in K. pygmaea. $\mathrm{Bar}=50 \mu \mathrm{m}$ (a, d, h); bar $=100 \mu \mathrm{m}(\mathbf{b}, \mathbf{c}, \mathbf{f})$; bar $=150 \mu \mathrm{m}(\mathbf{e}, \mathbf{g})$ spores (s) attached to
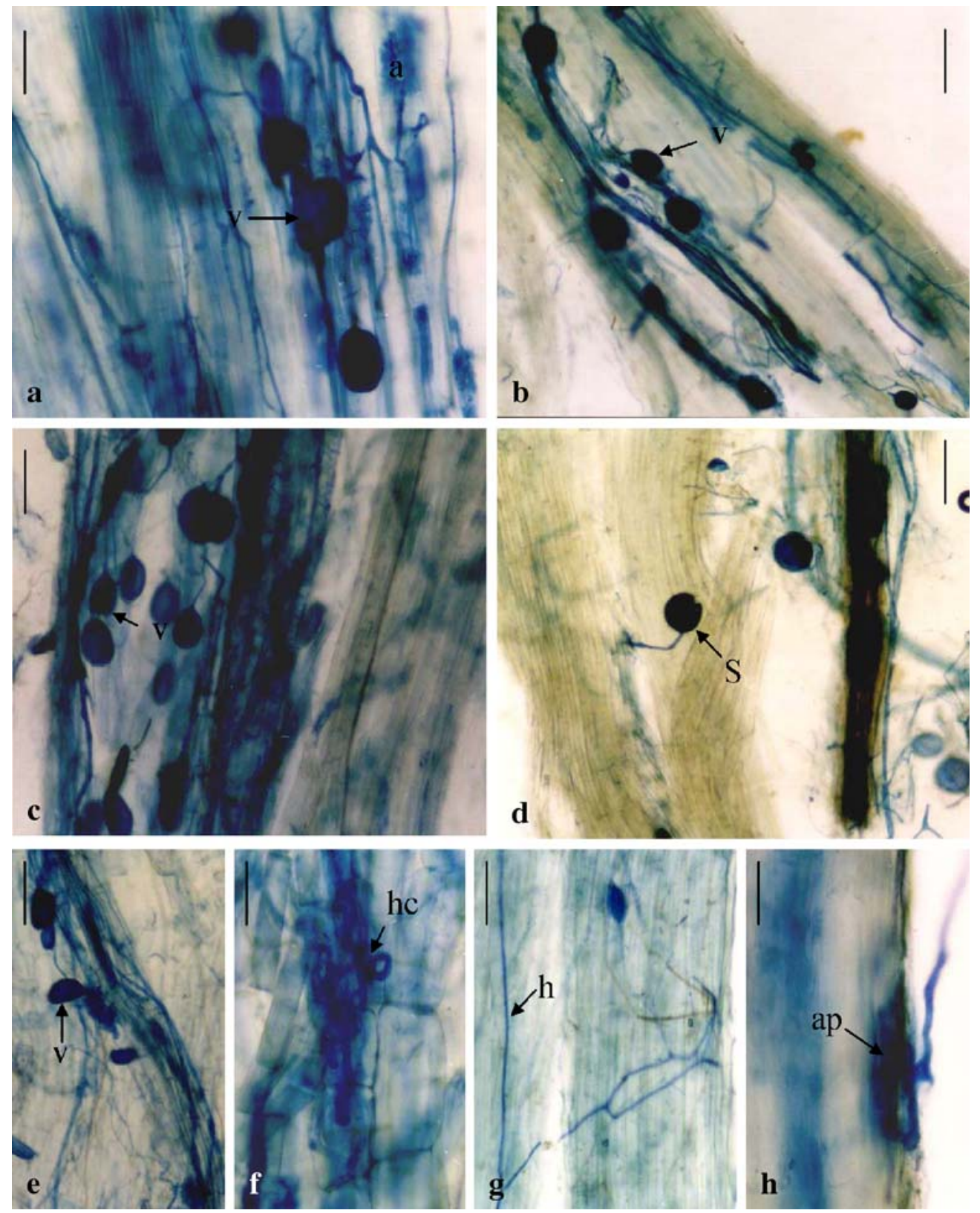

approximately $2 \mathrm{~kg}$ soil was collected from the rooting zone of the sedges to a depth of $20 \mathrm{~cm}$. Care was taken to avoid contamination from other plants. The soil samples were taken back to the laboratory, and soil texture and soil $\mathrm{pH}$ were determined immediately. After air-drying, the soil

samples were passed through a 2-mm sieve and stored at room temperature. Soil available $\mathrm{P}$ and organic matter content were determined using the methods described by $\mathrm{Lu}(2000)$.
Table 2 Isolation frequency, species richness, and relative abundance of the five AR fungal genera in Tibetan grassland sedges

$F$ Frequency, $R A$ relative abundance

\begin{tabular}{lclc}
\hline Genus & F (\%) & Richness (mean \pm SE) & RA (mean \pm SE) \\
\hline Glomus & 81.8 & $1.364 \pm 0.229$ & $19.0 \pm 5.8$ \\
Acaulospora & 63.6 & $0.955 \pm 0.184$ & $17.4 \pm 6.1$ \\
Scutellospora & 13.6 & $0.136 \pm 0.077$ & $0.7 \pm 0.4$ \\
Pacispora & 13.6 & $0.136 \pm 0.077$ & $5.6 \pm 3.2$ \\
Paraglomus & 9.1 & $0.091 \pm 0.064$ & $5.5 \pm 4.4$ \\
Archaeospora & 4.5 & $0.045 \pm 0.045$ & $0.1 \pm 0.1$ \\
\hline
\end{tabular}




\section{Root staining}

Roots were gently washed with water to remove adhering soil and carefully separated according to their morphological characteristics to avoid misinterpretation. Washed root samples were cleared in $10 \%(\mathrm{w} / \mathrm{v}) \mathrm{KOH}$ for $30 \mathrm{~min}$ at $90^{\circ} \mathrm{C}$, acidified in $2 \%(\mathrm{v} / \mathrm{v})$ lactic acid for $10 \mathrm{~min}$, and stained for $30 \mathrm{~min}$ at $90^{\circ} \mathrm{C}$ with $0.05 \%(\mathrm{w} / \mathrm{v})$ Trypan blue (Phillips and Hayman 1970). Roots that remained dark after clearing were bleached in alkaline $\mathrm{H}_{2} \mathrm{O}_{2}$ prior to acidification with lactic acid. Fifty $0.5-$ to $1-\mathrm{cm}$ root fragments from each sample were examined under a compound microscope $(100-400 \times)$ for AM fungal structures. The presence of arbuscules was used to designate AM associations (Brundrett 1991), and the presence of an AM association was considered doubtful when arbuscules were absent. The proportion of root length colonized was estimated by the root slide technique (Brundrett et al. 1996).

\section{Spore extraction and counting}

Spores were isolated from air-dried soil using the method of Daniels and Skipper (1982). Twenty grams of soil taken from each sample was suspended in 11 water and left to stand for $20 \mathrm{~min}$. The suspensions were passed through nested 500- and 45- $\mu \mathrm{m}$ sieves and wet sieved, followed by sucrose density gradient centrifugation. The AM fungal spores were counted on a grid-patterned dish under a binocular stereomicroscope.

\section{Culture establishment}

Trap cultures were established from fresh soil samples mixed with autoclaved sand in a ratio of $2: 1$. Clover (Trifolium repens L.) and sorghum (Sorghum vulgare Pers.) were used as host plants. Cultures were grown in a greenhouse at China Agricultural University for 5 months with a temperature regime of $28^{\circ} \mathrm{C}$ (day) and $15^{\circ} \mathrm{C}$ (night) and a 14-h photoperiod at a light intensity of $250 \mu \mathrm{mol} \mathrm{m}{ }^{-2}$ $\mathrm{s}^{-2}$ provided by supplementary illumination.

\section{Identification of AM fungi}

Spores of AM fungi isolated from the field soils and trap cultures were mounted on glass slides in polyvinyl-lactoglycerol (PVLG) or PVLG + Melzer's reagent $(1: 1, \mathrm{v} / \mathrm{v})$. The spores were examined microscopically and identified according to current taxonomic criteria (Schenck and Péréz 1990) and using the Internet information from the INVAM website (http:// invam.caf.wvu.edu).

Data analysis

AM fungal diversity was evaluated by spore density, relative abundance, isolation frequency $(F)$, and species richness. Spore density was expressed as numbers of AM fungal spores per $20 \mathrm{~g}$ dried field soil. Relative abundance was defined as the percentage of numbers of spores of the particular species or genera in the field soil. Data from field soil and trap cultures were combined to determine species composition. Isolation frequency was calculated as the percentage of samples in which the particular genus or species was present. Species richness was defined as numbers of AM fungal species per soil sample. Species diversity was measured by the Shannon-Weiner index as follows:

Shannon - Weiner index $=-\sum(\mathrm{Pi} \ln [\mathrm{Pi}])$

where:

$\mathrm{Pi}=\mathrm{ni} / \mathrm{N}$

and $n_{i}=$ number of spores in species $i$ and $N=$ total spore number of all species.

\section{Results}

Mycorrhizal status of sedges

AM fungal structures were observed in all the sedge roots examined, except for one ecotype of $K$. humilis (Table 1; Fig. 1). At species level, six species in our survey were mycorrhizal; $K$. humilis was facultatively mycorrhizal, and C. moorcroftii and Kobresia pusilla were of doubtful mycorrhizal status. The colonization pattern varied among the plant species and even among the ecotypes of individual species. Vesicles and intercellular aseptate hyphae were the most frequently observed structures present in the sedge roots examined. Vesicles were observed in 20 root samples (90\%), whereas arbuscules were observed in only 10 samples $(46 \%)$. Appressoria were present in $K$. humilis sampled from alpine steppe, $K$. prainii from both alpine meadow grassland and alpine steppe, and $K$. pygmaea from alpine meadow grassland. Intracellular coils were found only in Carex tibetica. No AM fungal structures were observed in the root sample of $K$. humilis from alpine meadow.

Colonization levels in sedges varied from 0 to $65 \%$, spore density from 8 to 189 per $20 \mathrm{~g}$ dried soil, and both varied greatly with plant species and ecotype (Table 1).

Table 3 Isolation frequency $(\geq 15 \%)$ and relative abundance of arbuscular mycorrhizal fungal species

\begin{tabular}{lll}
\hline Species & F $(\%)$ & RA (mean \pm SE) \\
\hline A. laevis & 22.7 & $3.5 \pm 1.6$ \\
A. scrobiculata & 31.8 & $5.8 \pm 2.2$ \\
G. claroideum & 18.2 & $5.3 \pm 4.2$ \\
G. intraradices & 22.7 & $2.4 \pm 1.5$ \\
G. mosseae & 27.3 & $2.8 \pm 1.5$ \\
\hline
\end{tabular}

$F$ Isolation frequency, $R A$ relative abundance 
Table 4 Arbuscular mycorrhizal species richness and diversity in different sedge species

\begin{tabular}{lll}
\hline Host plants & Species richness & Diversity \\
\hline C. capillacea var. linzensis & $3.5 \pm 2.0$ & $0.143 \pm 0.135$ \\
C. moorcroftii & $3.5 \pm 1.0$ & $0.201 \pm 0.120$ \\
C. tibetica & $1.0 \pm 0.0$ & $0.067 \pm 0.000$ \\
C. compressus & $2.4 \pm 0.6$ & $0.169 \pm 0.062$ \\
K. humilis & $2.0 \pm 0.4$ & $0.137 \pm 0.042$ \\
K. prainii & $4.5 \pm 2.1$ & $0.177 \pm 0.150$ \\
K. prattii & $3.0 \pm 0.0$ & $0.195 \pm 0.123$ \\
K. pygmaea & $3.0 \pm 1.4$ & $0.252 \pm 0.252$ \\
K. tibetica & $2.0 \pm 0.0$ & $0.070 \pm 0.000$ \\
\hline
\end{tabular}

Further, Pearson's correlation analysis of colonization levels and soil factors (soil $\mathrm{pH}$, organic matter, and available P) revealed a strong negative correlation between organic matter and colonization rate $(r=-0.733, P<0.00, n=22)$.

\section{AM fungal diversity}

Twenty-six taxa of AM fungi were isolated from the soil samples belonging to Glomus, Acaulospora, Paraglomus, Archaeospora, Pacispora, and Scutellospora (Table 2). Species richness in the survey areas was 2.73. Glomus and Acaulospora were the dominant genera, both in frequency and relative abundance. The five most commonly observed species were Acaulospora scrobiculata, Glomus mosseae, Glomus intraradices, Acaulospora laevis, and Glomus claroideum. Of these, A. scrobiculata was the most frequent and abundant species (Table 3).

The species richness and fungal diversity of nine sedge species differed substantially (Table 4). Species richness varied from 1.0 (C. tibetica) to 4.5 (K. prainii) and diversity from 0.070 (Kobresia tibetica) to 0.252 (K. pygmaea). No relationship existed between AM fungal diversity (diversity index, spore density) and soil factors (soil $\mathrm{pH}$, organic matter, and available P).

\section{Discussion}

Here, we report for the first time the mycorrhizal status of eight of the nine sedge species investigated. Only Cyperus compressus has previously been reported as mycorrhizal (Allsopp and Stock 1993; Muthukumar and Udaiyan 2000) and was defined as facultatively mycorrhizal when Muthukumar et al. (2004) summarized the published information on the mycorrhizal status of sedges. C. compressus was mycorrhizal in all ecotypes collected in our study. Only intercellular aseptate hyphae and vesicles were found in $C$. moorcroftii and $K$. pusilla. It has been reported that vesicles and hyphae are found in nonmycorrhizal hosts such as Cyperus iria and Cyperus rotundus (Koske et al. 1992; Giovannetti and Sbrana 1998). These plants can therefore be referred to as of doubtful AM status. K. humilis was found to be facultatively mycorrhizal in our survey. The incidence of mycorrhizal species in the present study was much higher $(67 \%)$ than the average level of $40 \%$ reported. Tibetan sedges therefore appear to be readily colonized by AM fungi.

Vesicles and intercellular aseptate hyphae were the most frequent structures present in the sedge roots, and this accords with earlier reports (Muthukumar et al. 2003; Muthukumar and Udaiyan 2000). The incidence of arbuscules was $46 \%$, not a very low value compared with other surveys (Muthukumar et al. 2003; Muthukumar and Udaiyan 2000). However, the percentage of root length colonized by AM fungi was very low in most root samples, and hyphal coils and appressoria were found in only a few specimens. The potential nutritional benefit of the mycorrhizal association in sedges therefore has yet to be ascertained. More detailed studies are necessary to ascertain the exact degree of mycorrhizal dependency of Cyperaceae and the functional aspects of the association in these Tibetan grassland communities.

The rarely colonized or nonmycorrhizal status of sedges is often attributed to the small amount or absence of mycorrhizal propagules in the soils that sedges inhabit (Peat and Fitter 1993). However, many sedges tend to be nonmycorrhizal even in the presence of AM fungal propagules (Van der Heijden et al. 1998), indicating that absence of AM fungal inoculum may not always explain the low incidence of AM in these plants. Spore densities in the rhizosphere of sedges were determined in our study, and there was no correlation between spore density and colonization rate. Other important factors likely to influence root colonization are soil properties. A strong negative correlation was found between soil organic matter content and root colonization rate. This is in agreement with the analysis of Muthukumar et al. (2004). However, root colonization was not related to important factors such as soil $\mathrm{pH}$ or soil available $\mathrm{P}$, which are shown to influence the mycorrhizal status of sedges (Lovera and Cuenca 1996; Muthukumar et al. 2004). One likely explanation could be the narrow data range in a particular habitat of this study. The mechanisms by which soil properties and other factors influence mycorrhizal associations still remain unclear and require more detailed research.

AM fungi are known to exhibit ecological specificity (McGonigle and Fitter 1990). There are no published reports on the AM fungal community associated with sedges under the climatic conditions prevailing on the Tibet plateau. Only a few studies have addressed the ability of AM fungi to survive winter freezing or drought stress (van der Heijden et al. 1998; Addy et al. 1998). The predominance of Glomus and Acaulospora is in accordance with Klironomos et al. (2001), who studied interspecific differences in AM fungal tolerance to freezing and dry conditions. These authors found that Glomus and Acaulospora were more frequently isolated in the field, and Glomus species were the least affected by freezing in pot experiment conditions, while drying gave more variable responses in colonization by AM fungi. Soil properties are important factors influencing the AM fungal community (Bever et al. 2001). Acaulospora species are often associated with acid soils. Most of the soils 
in our study were acidic, and this could be one explanation for our frequent detection of Acaulospora.

The colonization pattern varied among plant species, and even among ecotypes of particular plant species. K. humilis was mycorrhizal or nonmycorrhizal, which demonstrates that mycorrhizal fungi and their hosts occupy different positions on the "mutualism-parasitism continuum" under different environmental conditions (Johnson et al. 1997). The AM fungal community composition of particular sedge species varied with habitat type, similar to the results of Brundrett et al. (1999). G. mosseae and G. intraradices were also found by Klironomos et al. (2001) in similar environmental conditions. This indicates that some species have higher specific ecological adaptability.

Host species is an important factor influencing AM fungal species diversity (Brundrett 1991; Bever et al. 2001). Species richness and fungal diversity differed among the nine sedge species in our study. It has been shown that AM fungal diversity has a strong effect on the plant community, on plant productivity, and on succession (Allen 1991; Bever et al. 2001). The available data suggest an important ecological role for AM fungi in the Tibetan sedge community. However, full elucidation of the effects of AM fungi on the sedges still remains unclear, and the ecology and importance of $\mathrm{AM}$ associations require further detailed research.

Acknowledgements We thank the National Natural Science Foundation of China (Projects 30370818, 30260055, and 30470341) and the Royal Society (China Exchanges Project 15360) for financial support.

\section{Appendix}

AM fungal species and their frequency of isolation from rhizosphere soils of sedges

\section{Species}

Frequency

Acaulospora appendicula Spain, Sieverding \& Schenck 4.5

Acaulospora dilatata Morton $\quad 9.1$

Acaulospora laevis Gerd. \& Trappe 22.7

Acaulospora mellea Spain \& Schenck $\quad 4.5$

Acaulospora scrobiculata Trappe $\quad 31.8$

Acaulospora spinosa Walker \& Trappe $\quad 9.1$

Acaulospora sp. 1

Acaulospora sp. 2

Archaeospora gerdemanni (Rose, Daniels \& Trappe) 4.5

Morton \& Redecker

Glomus claroideum Schenck \& Sm. emend Walker \& 18.2

Vestberg

Glomus convolutum Gerd. \& Trappe

4.5

Glomus clarum Nicolson \& Schenck

4.5

Glomus diaphanum Morton \& Walker

9.1

Glomus etunicatum Becker \& Gerdemann

9.1

Glomus geosporum (Nicol. \& Gerd.) Walker 9.1

Glomus glomerulatum Sieverd.

4.5

Glomus intraradices Schenck \& Smith
Species

Glomus luteum Kennedy, Stutz, et Morton

Frequency

Glomus manihotis Howeler, Sieverd. \& Schenck

4.5

4.5

Glomus mosseae (Nicol. \& Gerd.) Gerd. \& Trappe 27.3

Glomus verruculosum Błaszk

9.1

Glomus sp. 1

9.1

Pacispora scintillans (Rose \& Trappe) Oehl \& Sieverd 13.6

Paraglomus occultum (Walker) Morton \& Redecker 9.1

Scutellospora calospora (Nicol. \& Gerd.) Walker 9.1

Scutellospora verrucosa (Koske \& C. Walker) 4.5

Walker \& Sanders

\section{References}

Addy HD, Boswell EP, Koide RT (1998) Low temperature acclimation and freezing resistance of extraradical VA mycorrhizal hyphae. Mycol Res 102:582-586

Allen ME (1991) The ecology of mycorrhiza. Cambridge University Press, New York

Allsopp N, Stock WD (1993) Mycorrhizal status of plants growing in the Cape Floristic Region, South Africa. Bothalia 23:91-104

Bever JD (2002) Host-specificity of AM fungal population growth rates can generate feedback on plant growth. Plant Soil 244:281-290

Bever JD, Schultz PA, Pringle A, Morton JB (2001) Arbuscular mycorrhizal fungi: more diverse than meets the eye, and the ecological tale of why. Bioscience 51:923-931

Brundrett M (1991) Mycorrhizas in natural ecosystems. Adv Ecol Res 21:171-313

Brundrett M, Bougher N, Dell B, Grove T, Malajczuk N (1996) Working with mycorrhizas in forestry and agriculture. ACIAR Monograph 32. Australian Centre for International Agricultural Research, Canberra

Brundrett MC, Jasper DA, Ashwath N (1999) Glomalean mycorrhizal fungi from tropical Australia II. The effect of nutrient levels and host species on the isolation of fungi. Mycorrhiza 8:315-321

Burrows RL, Pfleger FL (2002) Arbuscular mycorrhizal fungi respond to increasing plant diversity. Can J Bot 80:120-130

Daniels BA, Skipper HD (1982) Methods for the recovery and quantitative estimation of propagules from soil. In: Schenck NC (ed) Methods and principles of mycorrhizal research. American Phytopathologic Society, St. Paul, MN, pp 29-35

Fuchs B, Haselwandter K (2004) Red list plants: colonization by arbuscular mycorrhizal fungi and dark septate endophytes. Mycorrhiza 14:277-281

Giovannetti M, Sbrana C (1998) Meeting a non-host: the behaviour of AM fungi. Mycorrhiza 8:123-130

Harley JL, Harley EL (1987) A checklist of mycorrhiza in the British flora. New Phytol 105 (Suppl):1-102

Hirsch AM, Kapulnik Y (1998) Signal transduction pathways in mycorrhizal associations: comparisons with the Rhizobiumlegume symbiosis. Fungal Genet Biol 23:205-212

Johnson NC, Graham JH, Smith FA (1997) Functioning of mycorrhizal associations along the mutualism-parasitism continuum. New Phytol 135:575-586

Klironomos JN, Hart MM, Gurney JE, Moutoglis P (2001) Interspecific differences in the tolerance of arbuscular mycorrhizal fungi to freezing and drying. Can J Bot 79:1161-1166

Koske SE, Gemma JN, Flynn T (1992) Mycorrhizae in Haiwaiian angiosperms: a survey with implications for the origin of the native flora. Am J Bot 79:853-862

Lovera M, Cuenca G (1996) Arbuscular mycorrhizal infection in Cyperaceae and Gramineae from natural, disturbed and restored savannas in La Gran Sabana, Venezuela. Mycorrhiza 6:111-118 
Lu RK (2000) Methods of soil and agricultural chemistry analyses (in Chinese). China Agricultural Science and Technology Press, Beijing

McGonigle TP, Fitter AH (1990) Ecological specificity of vesiculararbuscular mycorrhizal associations. Mycol Res 94:120-122

Muthukumar T, Udaiyan K (2000) Arbuscular mycorrhizas of plants growing in the Western Ghats region, Southern India. Mycorrhiza 9:297-313

Muthukumar T, Sha LQ, Yang XD, Cao M, Tang JW, Zheng Z (2003) Mycorrhiza of plants in different vegetation types in tropical ecosystems of Xishuangbanna, southwest China. Mycorrhiza 13:289-297

Muthukumar T, Udaiyan K, Shanmughavel P (2004) Mycorrhiza in sedges: an overview. Mycorrhiza 14:65-77

Newman EI, Reddell P (1987) The distribution of mycorrhizas among families of vascular plants. New Phytol 106:745-751

Peat HJ, Fitter AH (1993) The distribution of arbuscular mycorrhizas in the British flora. New Phytol 125:845-854

Peterson RL, Bradbury SM (1995) Use of plant mutants, intraspecific variants and non-hosts in studying mycorrhiza formation and function. In: Varma A, Hock B (eds) Mycorrhiza. Springer, Berlin Heidelberg New York, pp 521-560
Phillips JM, Hayman DS (1970) Improved procedures for cleaning and staining parasitic and vesicular arbuscular mycorrhizal fungi for rapid assessment of infection. Trans Br Mycol Soc 55:158-160

Regvar M, Vogel K, Irgel N, Wraber T, Hildebrandt U, Wilde P, Bothe H, (2003) Colonization of pennycresses (Thlaspi spp.) of the Brassicaceae by arbuscular mycorrhizal fungi. J Plant Physiol 160:615-626

Schenck NC, Péréz Y (1990) Manual for the identification of vesicular-arbuscular mycorrhizal fungi. INVAM, University of Florida, Gainesville

Smith SE, Read DJ (1997) Mycorrhizal symbiosis, 2nd edn. Academic Press, London

Tester M, Smith SE, Smith FA (1987) The phenomenon of 'nonmycorrhizal' plants. Can J Bot 65:419-431

van der Heijden MGA, Klironomos JN, Ursic M, Moutoglis P, Streitwolf-Engel R, Boller T, Wiemken A, Sanders IR (1998) Mycorrhizal fungal diversity determines plant biodiversity, ecosystem variability and productivity. Nature 396:69-72 